УДК 001; 37.4

Oleksandr Yu. Burov

Dr.Sc. (Eng.), leading researcher of Department of technologies of open learning environment

Institute of Information Technology and Learning Tools of the NAES of Ukraine, Kyiv, Ukraine

ayb@iitlt.gov.ua

\title{
INDIVIDUAL ABILITIES AND LIFELONG LEARNING
}

\begin{abstract}
This paper describes new and emerging technologies in education, learning environments and methods that have to satisfy lifelong learning, from school age to retirement, on the basis of the psychophysiological model of the cognitive abilities formation. It covers such topics as: evaluation of a human (accounting schoolchildren, youth and adults features) abilities and individual propensities, individual trajectory of learning, adaptive learning strategy and design, recommendation on curriculum design, day-to-day support for individual's learning, assessment of a human learning environment and performance, recommendation regards vocational retraining and/or further carrier etc.). The specific goal is to facilitate a broader understanding of the promise and pitfalls of these technologies and working (learning/teaching) environments in global education/development settings, with special regard to the human as subject in the system and to the collaboration of humans and technical, didactic and organizational subsystems.
\end{abstract}

Keywords: human abilities; development; learning environment; psychophysiological model; safety.

\section{INTRODUCTION}

It is recognized that global changes in education aimed at ensuring tasks to account the transition from the post-industrial to a digital era as well as to the knowledge society when a human individual cognitive and creative ability become crucial for the mankind development [1]. Modern education needs to be more and more individual-oriented, innovative, securing individual psychophysiological abilities and development including network (as a main learning/nurturing environment) security and safety [2;3].

Nowadays social, business, education/learning actions take place globally and in many time zones. Human knowledge and intelligence are now being systematically transferred to computers, allowing them (e.g. in the form of robots or automated systems) to operate autonomously often even far away from the original time and space of its human originators. Moreover, that notation of space has expanded: new spaces have opened up like the cyber space of Internet, cloud education etc. They are accompanied by new technologies that need to solve appropriate tasks: to evaluate and to develop new and emerging technologies needed in education, learning environments and methods that have to satisfy lifelong learning, from pre-school age to retirement [4].

The problem setting. Giftedness and talent are associated with creativity, cognitive abilities, intelligence, innovative thinking and other psychological qualities. To date, challenges to education are associated with modern possibilities, innovative technologies and increasing attention to student abilities to obtain knowledge and skills. Using the concept of context-based cognition it is assumed that learner's individual construction of knowledge should take place within a certain context, which is similar to the context in which this knowledge should be applied in the future [5].

At the same time, it is known that human cognitive opportunities can vary from day-today depending on his/her functional state and fitness-for-work [6]. As a result, appropriate changes can impact a human ability to adapt in a particular learning environment, to perceive 
and to conceive new information, to use it, to get knowledge and skills and to prevent its inefficiency. Besides, nowadays it has been revealed a negative impact of a human's work in ICT over a long period on his/her health and mental efficiency. This is especially important for children and young people whose organism is more sensitive and unstable comparing to adult one. Health deviations have impact on a child mental efficiency in learning process as a consequence of this. Some of them have fluctuation nature in their development. As a result, efficiency of learning and talent nurturing depend not only on innate child properties, but on information contour of functional system of learning as a specific type of activity maintenance.

Analysis of recent studies and publications. We believe that difficulties to assess and to predict students' abilities and achievements are result of lack of recognized definition of giftedness and measurement tools [7], accounting actual environment of learning [8] and dynamic nature of giftedness and talent development [9].

At the same time, it was stated that the most fruitful approach to understand mechanisms of activity is a theory of functional systems proposed by P.Anokhin [10] and his disciples (K.Sudakov, A. Navakatikyan) who proposed the concept of the activity functional system that connects in one model physiological systems state, conditions of the work environment and the goal of activity. According to it, a human activity is accompanied by creation and maintenance of functional systems that are activated dominant brain structures and correspond activity of one or another organism systems and are quite enough stable for particular type of the human performance [5]. But this is not enough to understand to what degree it can explain reasons of insufficient accuracy of a human performance prediction.

The purpose of the article is to describe psychophysiological basis (concept and model) of a human learning process, as well as a human view on network-born threats for a human (users of all ages) health and performance.

\section{METHOD}

The method used is based on the model proposed by the author. This model is a development of the basic idea of P.Anokhin on formation and functioning of the "functional system of activity" [10].

Any human activity of mental type could be analyzed as an operator work, because professional operator (pilot, power unit dispatcher, driver etc.), manager and learner have to do with the objects indirectly through the information model of process activities. Work (activity) of such a type has its own specificity which manifests itself in a workload, because information processes are not as discrete as continuous [5]. The reason is that the conceptual model of activity (describing a human psychological adaptation to work) is expanded in the time independently on external process and a human activity consists in discrete comparison of the information obtained from outside with the model existing constantly. I.e., conceptual model can be considered as an information stratum of professional work, and physiological chain ,afferent inputs - activity acceptor - physiological control - effectors - act” is an energetic stratum [11]. The goal of professional training is forming the conceptual model of activity of a particular type and/or of carrying out the particular task. It means creation of ,information contour" that exists and is maintained in activated state in carrying out process for purposeful activity and embraces afferent inputs, decision making block, activity acceptor and act program, as well as the object of activity (is represented as information model in case of operator-watcher that creates the information contour together with the imagine conceptual model).

Energetic and information stratums can be represented as two contours which partly coincide at the level of morphological structures and functions, but partly differ because of 
including into the information contour an activity object that does not participated in the energetic contour of the organism regulation, but is an inalienable part of the information contour. Human activity is a mediator between internal and external environment of organism, projection of structural-function specific of professional homeostasis on the operator work. Output parameters of the activity program (activity effectors) stand in the information contour as parameters of capability. In such a context, operator's activity is an activity program realized as physical and/or mental acts in external environment.

\section{RESULTS}

\section{Research hypotheses}

The specific of learning activity consists in that informative processes are more involved than energetic ones, and conceptual model of learning work is a result of psychophysiological adaptation to this activity [11]. This is relatively close to an operator activity and, from substantial viewpoint, consists in discreet comparison of information received from the educating system with the conceptual learning model used, in carrying out a particular task. In other words, it consists in forming and using an ,,information contour" that exists in active state during the process of purposeful activity (Fig.1). This contour includes afferent inputs, decision making block, act acceptor and act program, as well as the object of acting (information model for operator). This hypothesized model of psychophysiological maintenance of mental activity was developed as an advancement of P.Anokhin's theory of functional systems.

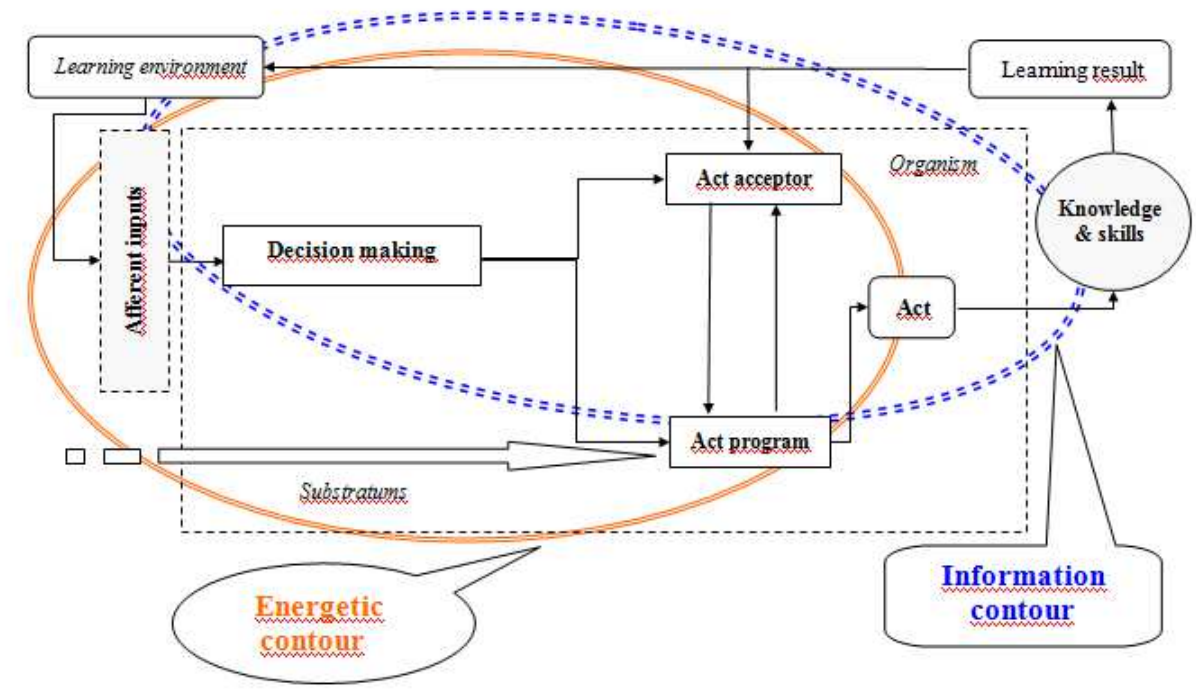

Fig. 1. Theoretical scheme of the functional system of learning activity, where regulation (Anokhin, 1973, [10]) was divided into two contours - information and energetic ones

It is clear that stability level of circulation in the information loop can be provided by its dynamical fluctuation according to changes in levels of activation of certain physiological systems subject to constant resultant of power. In formalized form, this means that if the index of indicator level of information circulation $\boldsymbol{i}$ (rate) in the information loop is constant (ie, periodic with frequency $\boldsymbol{\omega} \boldsymbol{i} \rightarrow \boldsymbol{0}$ ), mental capacity $\boldsymbol{R}$ is at one level, and integrated parameters of physiological systems $\varphi_{j}$ change of characteristic for their frequency $\omega_{j}$, then 


$$
F=A f(\omega)=\sum_{j} B_{j} \varphi_{j}\left(\omega_{j}\right) \approx \text { const }
$$

where $\boldsymbol{A}, \boldsymbol{B} \boldsymbol{j}$ - average values of estimated parameters in the range of observation.

Description is given from viewpoint of both theory of functional systems and new "vortical model" of ability development as a dynamic transformation [12]. The latter means that a human natural inclinations transformation into abilities can involve physiological, psychological and external sources as "developing environment" that create particular abilities as a specific combination of abilities existing only in interaction with actual environment. And this interaction has dynamic nature depending on power and rate of three sources circulation that involve information, knowledge and skills as a catalyst saturating the giftedness structure created.

Afferent inputs correspond to well-known sensory systems and could be divided into:

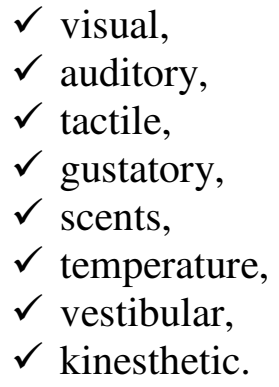

In such a context analyzers' characteristics could be as follows: energetic, informational, spatial and temporal.

\subsection{Changes of cognitive abilities in day-to-day intervals}

It was confirmed that human ability to cognitive performance is not stable over time span that impacts on human mental performance efficiency [11]. This corresponds the idea of the central role of cognitive processes in prediction of training and operation. Oscillations of psychophysiological indices of a human state and capacity have exogenous and endogenous nature.

The model can help to answer the questions: what to measure, assess and predict? Main issues to be accounting in this context are as follows:

1. Measurement should be a tool, not a goal.

2. Parameters of the information contour should be measured for each stage of a student activity:

$\checkmark$ Professional adaptation-disadaptation.

$\checkmark$ Day-to-day fitness-for-learning.

$\checkmark$ Current learning performance degradation.

This method and its application to fitness-for-learning assessment are discussed using results of study of 20 intellectually gifted school boys' cognitive abilities on a month day-today basis. Subjects participated in two types of observation: (1) preliminary assessment of specific abilities for particular areas of mental activity (math, science, technical etc.), (2) dayto-day monitoring of performance the series of cognitive tasks [8].

The effectiveness of research psychophysiological techniques considerably rises in case of usage not of a set of tests, but of a psychodiagnostic system. To solve this task, it has been developed the computer system of psychophysiological researches of a human psychomotor and cognitive activities in condition of research laboratories and rehabilitation centers. 
Experiments included psychological tests performance by subjects at the computer display and simultaneous measurement of physiological parameters. They were used tests as follows: short memory, perceptual (searching of missed numeral), cognitive (logic-combinatorial) [12]. In all tests we registered time of each task performance in milliseconds, correct (expected) and really entered answers. Besides, we used a subjective state assessment of the examinees by means of the reduced variant of the test "General_state - Activity - Mood" (GsAM) at the beginning and at the ending of the test session (indices of mood mood, serviceability $F f D$, attention atten, anxiety anxiety, prior to the beginning labeled by "0").

We registered a heart rate $H R$ and blood pressure (systolic $B P s$, diastolic $B P d$ ) as indices of physiological "cost" of activity and the human state by means of the cardiomonitor "Solveig". Indices $H R, B P s$ and $B P d$ were stored over 5 min prior to the tests beginning (index " 0 ") and 5 min after finishing (relaxation) as well.

The specific of the research technique consisted in to study the variability of psychophysiological indices registered when subjects performed cognitive and perceptual tests and under influence of infradian rhythms of a various origin. Each examinee took part in experiments with constant workload in the same phase of day to eliminate the circadian effect.

The results of influence of solar activity on a human health and some physiological systems are known, however it is lack of study results regards cognitive activity associating with heliophysic parameters in the scientific literature to date. In our preliminary pilot researches the precise connection between effectiveness of operator activity and parameters of a solar wind (SW) was revealed. With the purpose to study this phenomenon we registered indices of proton component of a solar wind - velocity SWsp $(\mathrm{km} / \mathrm{s})$ and density SWden (proton/sm3) on the data from Internet site NASA [13], as well as parameters of the geomagnetic field (GMF) - planetary index Ks and index of "equivalent amplitude" A.

Average values of physiological parameters testers for testing days indicate the individual character of their dynamics as in the initial state (immediately after school) and after the test activity. Comparison of changes in the nature of physiological parameters as a reaction to stress (cognitive tests are simple and conform to the logical skills of Grade 1 pupils of secondary school), indicates that even these activities can serve as a functional test of the occurrence of fatigue, which was found in previous studies (Fig.2).

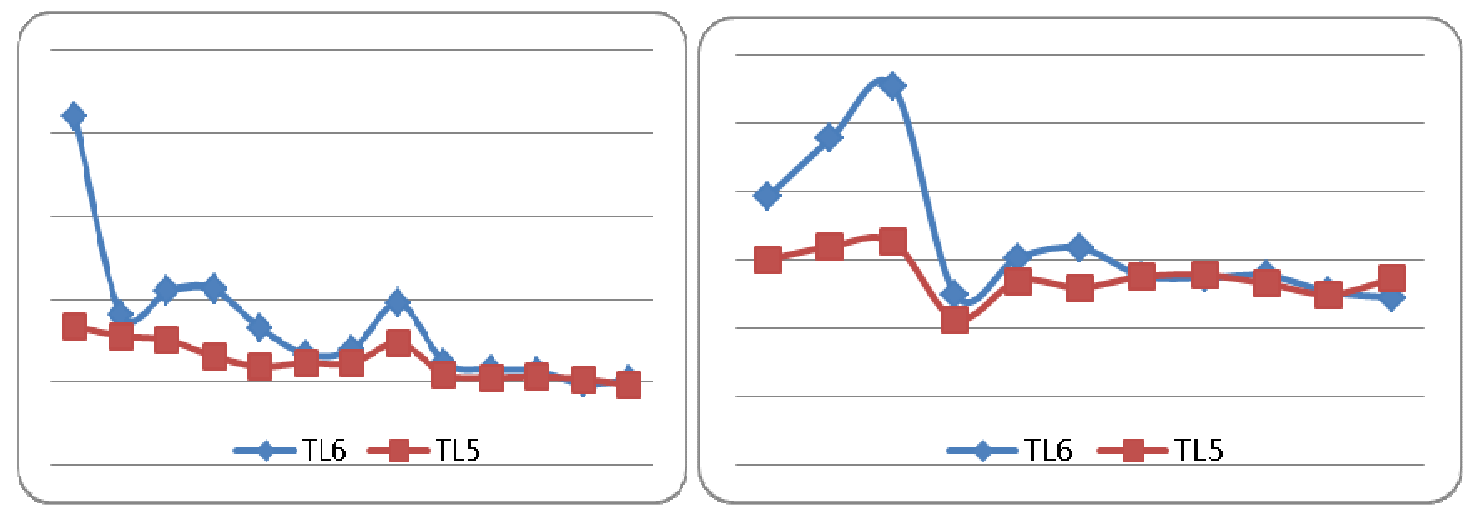

Fig. 1. Daily dynamic run-time tests of two subjects. On the axis: abscissas - days of test performance, ordinate - the average task time performance in tests T6 and T5, ms.

It has been revealed significant increase in heart rate in the first subject, but other indices of myocardial activity did not change. This subjective assessment of mood under the influence of the test after the test performance was more stable comparing to the original state 
(just after the last lesson). Thus, different tendencies of objective performance changes, selfassessment and physiological changes in time, under learning and external factors impact need to be accounting as the comprehensive approach in education process to increase its efficiency and to reduce its negative impact on students' health.

\subsection{Possible applications of the model to control students' cognitive performance}

Practical realization of these ideas is applied for the cybernetic mechanism of a human performance control. There is the set of psychophysiological parameters of human $\mathbf{P}$, which are related to forming and realization of his capacity. The set of his professionally important qualities, parameters of professional senescence and current capacity is a number of the parameters of operator professional activity D. The task of synthesis of the system for psychophysiological prediction of operator capacity is the task of optimum reflection $\mathbf{P}$ on $\mathbf{D}$, that provides maximal quality of functioning SLTS $\mathbf{Q}$ subject to the system cost $\mathbf{C}$, which does not exceed a possible level $\mathbf{C}_{\text {lim }}:[\mathbf{p} \in \mathbf{P}] \mathbf{m}\left[\mathbf{D}^{*} \subset \mathbf{D}\right]$, where $\mathbf{m}-$ operation of optimum reflection of elements $\mathbf{P}$ on the set of elements $\mathbf{D}$; $\mathbf{D}^{*}$ - optimum set of parameters of professional activity

\section{$D_{0} \in D$}

$$
D_{0}=\arg \max Q(D) \text { under } C \leq C_{\text {lim. }}
$$

In the general case of ergonomics approach to the analysis of efficiency of the system Human-Technique-Environment (SHTE), the estimation and purpose of prognosis of functional state and human capacity $\boldsymbol{U}$ in SHTE is to provide maximal quality of functioning of the system $\mathbf{Q}$, which relies on the realized of operator capacity $\mathbf{R}$, organization of the system $\mathbf{O}$, the state of equipment $\mathbf{E}$, inter-element interface $\mathbf{I}$, dynamics of SHTE changes in time t. Such task is described as:

$$
\hat{U}(t)=\underset{\breve{R}, \mathscr{O}, \breve{E}, \breve{I}}{\operatorname{argmax}} \mathbf{Q}(\mathbf{t})=\underset{\check{R}, \mathscr{O}, \breve{E}, \breve{I}}{\operatorname{argmax}} f[\mathbf{R}(\mathbf{t}), \mathbf{O}(\mathbf{t}), \mathbf{E}(\mathbf{t}), \mathbf{I}(\mathbf{t}), \mathbf{t}],
$$

$$
\text { where } \breve{R}(t) \in \mathbf{R}(\mathbf{t}), \breve{O}(t) \in \mathbf{O}(\mathbf{t}), \breve{E}(t) \in \mathbf{E}(\mathbf{t}), \breve{I}(t) \in \mathbf{I}(\mathbf{t}) \text {. }
$$

If evaluation of performance $\hat{\boldsymbol{U}} \rightarrow \boldsymbol{U}$, quality of functioning SHTE can achieve the maximal value $\mathbf{Q}>\mathbf{Q}_{\text {max }}$ by using a human maximal capability.

It has been developed the system to optimize students' work with ICTs in regards to choose optimal form of learning for a particular moment with advanced proposals for a student that gave flexibility of work in particular day accordingly to his/her functional state (to take lectures, to work in interactive mode with computer or teacher, to make applied tasks, to work in library, to work in Internet etc. or to delay an active form of teaching for another time). This could give a tool to intensify the education time by way to re-allocate efforts and to optimize a time use.

The physiological mechanisms of the adaptation of a student's activity functional system to the education environment may vary depending on the conditions, location and time of his/her activity. Hence, proposed approach may contribute to improve human working conditions, if it takes into account not only macroergonomic requirements (spatial aspect of human interaction with the environment), but also ergodynamic ones (temporal aspect), direct or indirect measurement of possible psychophysiological changes when learning makes it possible to review a functional state of a student, which helps to predict his/her individual fitness and reliability for effective learning process. Because, learning activity has quite 
similar features to other types of cognitive work, one can suppose that general cognitive findings could be valid for learning as well [14].

Task performance measures before current learning activity should be focused on rate and accuracy of information processing. The student's test performance, which precedes a work with the computer system, consists in decision of the same type of cognitive and perceptual tasks. The time and accuracy of each task performance are registered. Task performance time values produce during research a time series. The further analysis of time series permits to reveal the "waves" that are induced by the regularity of fluctuation of task performance time.

Computer method allows varying flexibly the tempo, volume and complexity of test tasks for different levels of cognitive and perceptual complexity with and without interferences. The research method foresees to investigate and take into account the biorhythms influence on the human behaviour and fitness for duty with periods up to 1 month.

According to schedule, a student came to the computerized workplace and performed a cognitive test with the computer sub-system and got as a result a time of his/her effective work with computer for current day. That recommended time could be coordinated with the student's supervisor and a real time could be changed.

Electronic education gives new opportunities such as:

$\checkmark$ flexibility of education programs - a student can choose courses, teachers, time of active work, etc.;

$\checkmark$ individualization of education process - re-allocate time and education resources in dependence on a student's individual psychophysiological possibilities to make this process more intensive and to give equal opportunities for both common people and people with disabilities.

Such results of the state assessment can help a student to make a decision what type of work in particular day is preferable accordingly to his/her functional state:

$\checkmark$ to take lectures,

$\checkmark$ to work in interactive mode in ICT,

$\checkmark$ to work in interactive mode with a teacher,

$\checkmark$ to make applied tasks,

$\checkmark$ to work in library,

$\checkmark$ to work in Internet,

$\checkmark$ to perform individual tasks etc.

$\checkmark$ to delay an active form of teaching for another time.

Although further work is required to gain a more complete understanding of such a tool's use, it is clear that this could give a student an opportunity to intensify a time by way to re-allocate his/her effort and to optimize a time use. Another aspect of the same problem is an adaptive automation of human-computer interaction in accordance with a student functional state.

The current study provides further evidence that traditionally education managers do not analyze such opportunity to make the education process more effective, because a student must study as it is done. This way is aimed to a "group norm", but not to an individual, especially gifted and talented.

\subsection{Networking threats}

As it was stated [2], not so far ago a human place and role in networks could be described as a terminal element (node) linked to other elements with its specific interface 
(having human and technical parameters). Currently, when a human life and activity have more virtual nature, information environment (network) becomes an independed factor, because process of a human presence as well as results of his/her activity lose their localization in space and in time, as well as could be affected at anytime and anywhere. Even more, those results could «live» inside the network «infinitely», because technical resources holding them are distributed, flexible and supported continuously.

Recommendations for improving a human psychophysiological security have been developed and described [4]. The further development of ergonomics criteria could be developed accounting the new human activity nature and a multiaspect ergonomic analysis $[15,16]$.

Active usage of networks, especially by children and youth, is accompanying by increase of different kind of threats coming from networks [17[. Particularly acute this problem obtained with development and use of social networks. Most active hidden threats (for children) emanating from the computer network, stacked in the following classification scheme :

$\checkmark$ Viruses attacks.

$\checkmark$ Cyber-crime (spamming, carding, phishing, botnets etc.).

$\checkmark$ Threats from network-surfing (cyber-bulling, "adult" content, illegal content, online violence, disclosure of private information, pay services etc.).

It is recommended to consider the interaction between schoolchildren and students with computer network as the system "Human-technique-environment" [17]. In such a system, the computer network serves as a machine that allows us to consider the impact of the network on a human as a threat coming from the machine. Accordingly, the concept of "network effect" can be revealed through the concept of "operator error and reducing the quality of operator activity', 'impact of computer games" and "Internet addiction".

Threats coming from networks can be classified into the following types: active and passive, overt and hidden, current and deferred.

Using ergonomic approach and methodology, it is possible to evaluate active hidden dangers as a hierarchical set of indicators:

$\checkmark$ one integrated (complex) index - the level of danger as a result of a computer network; index is a dimensionless quantity and is on the upper level assessment system;

$\checkmark$ group three indicators - levels of hazards caused by virus attacks, cyber-crime or internet surfing; indicators are dimensionless quantities and are at average levels of the system assessments;

$\checkmark$ a set of individual indicators of the group of one or set of threats; indicators are also dimensionless quantities and are on the lower level grading system.

From educational domain context, target groups of cyber security (CS) could be classified as follows:

$\checkmark$ Students as operators

$\checkmark$ Educators

$\checkmark$ Children/Youth (in general)

$\checkmark$ Population (in general, as social environment for children).

The human view regards CS is a fruitful approach to define tasks, resources and ways of solution the above mentioned challenges [17]. The Human View (HV) could be defined as a method for human-system integration to identify and assess the human specific aspects 
(abilities and limitations) of a total systems engineering approach for system design, development and usage.

Human View - constraint.

If a system requires a human interface, then the system must be designed to accommodate the human as a passive and as an active element, creating sub-system for safety both for and from a human.

Human View - functions.

Provide a justification for the allocation of tasks and functions between the humans and machines depending on a human current status and capability.

Human View - role.

Describes the roles that have been defined for the human interacting with the system and its possible changes over mission time (f.e., from simple executor to leader and/or commander) accounting his competencies, ability for tasks generation, leadership etc.

Human View - human network.

Team performance impacts, re-allocation, dependencies and communication.

These views should be a basis ergonomically grounded for design and creation new and safety educational tools, as well as should be accounted in usage of different educational recourses [18], especially cloud-oriented [19].

\section{CONCLUSIONS AND OUTLOOK}

Digital life and activity give new opportunities for people and new problems in different domains including education.

Broader understanding of the promise and pitfalls of learning technologies and working (learning/teaching) environments in global education/development settings could be useful with special regard to the human as a subject in the system and to the collaboration of humans and technical, didactic and organizational subsystems.

Global changes in education aimed at ensuring the transition from the post-industrial to a digital era as well as to knowledge society when human individual cognitive and creative abilities become crucial for the further development of mankind.

Psychophysiological model of learning and cognitive abilities development could be a basis for more effective design of learning organization and process.

They are proposed to discussion: identification of areas in which coordinated research efforts are required to expand an understanding of these network technologies, their effectiveness, the potential risks, and the potential benefits of new ways to educate, learn and collaborate.

\section{REFERENCES}

1. Future of education: lessons uncertainty (Abstracts of the World Economic Forum in Davos). January 2016. - Access: http://biz.liga.net/upskill/all/stati/3225018-budushchee-obrazovaniya-urokineopredelennosti.htm

2. Kleinberg Jon. "Analysis of large-scale social and information networks," Philosophical Transactions of the Royal Society A, v.371, 2013, p. pp. 1471-2962.

3. Raspopovic, M., Cvetanovic, S., \& Jankulovic, A. (2016). Challenges of Transitioning to e-learning System with Learning Objects Capabilities. The International Review of Research in Open and Distributed Learning, 17(1).

4. Burov O. Lifelong Learning: Individual Abilities vs. Environment \& Means // Ermolayev, V., Spivakovsky, A., Nikitchenko, M., Ginige, A., Mayr, H. C., Plexousakis, D., Zholtkevych, G., Burov, O., Kharchenko, V., and Kobets, V. (Eds.): ICT in Education, Research and Industrial Applications: 
Integration, Harmonization and Knowledge Transfer. Proc. 12th Int. Conf. ICTERI 2016, Kyiv, Ukraine, June 21- 24, 2016, CEUR-WS.org, online.

5. Bednar, A.K., T.M. Duffy, and J.D. Perry (1992). "Theory into practice: How do we link?" in T. Duffy and D. Jonassen (Eds.) Constructivism and the technology of instruction: A conversation (pp. 17-34). Hillsdale, NJ: Erlbaum.

6. Burov, A. (1986). Evaluation of functional state of operators on parameters of mental serviceability. Human Physiology, 2, 29-36.

7. Conceptions of Giftedness (2005). 2nd Edition. Edited by: Robert J. Sternberg and Janet E. Davidson, Lewis and Clark College, Portland. 480 pp.

8. Horowitz, F. D. (1987). A developmental view of giftedness. Gifted Child Quarterly, 31(4),165-168.

9. Gagné, F. (2003). Transforming Gifts into Talents: The DMGT as a Developmental Theory. In N. Colangelo \& G. A. Davis (Eds.), Handbook of gifted education (3 ${ }^{\text {rd }}$ ed.), pp. 60-74. Boston: Allyn and Bacon.

10. Anokhin, P.K. (1973). Principle questions of the general theory of functional system. Principles of the system organization of function. Moscow: Science, 5-61. Russian.

11. Burov O., Tsarik O. Educational workload and its psychophysiological impact on student organism. Work. Volume 41, Supplement 1/ 2012. Pp. 896-899.

12. Burov O.Yu. Dinamics of development of intellectual abilities of gifted person in teenagers / O. Yu. Burov, V. V. Rybalka, N. D. Vinnyk, V. V. Rusova, M. A. Percev, I. O. Plaksenkova, M. O. Kudrjavchenko, A. B. Saghalakova, Ju. M. Chernjak; Za red. O. Ju. Burova.- K. : Tov «Informacijni systemy», 2012.- 258 s. SEC's Anonymous FTP Server (Solar-Geophysical Data). http://sec.noaa.gov/ftpmenu/lists/ace2.html SEC's Anonymous FTP Server (Solar-Geophysical Data). http://sec.noaa.gov/ftpmenu/lists/ace2.html

13. Veltman H., Wilson G., Burov O. Cognitive load. NATO Science Series RTO-TR-HFM-104.- Brussels, 2004. Pp. 97-112.

14. Pacholsky L. 2004. A new methodological paradigm of a multiaspect ergonomic analysis. In: Dilemmas and issues of modern ergonomics and work safety education and researches. Editors: L.M.Pacholski, J.S.Marcinkowski, W.M.Horst. Poznzn, 2004. 413-426.

15. Wilson John R., Carayon Pascale. Systems ergonomics: Looking into the future - Editorial for special issue on systems ergonomics/human factors. Applied Ergonomics. Volume 45, Issue 1, January 2014, Pages 3-4.

16. Burov O. Virtual Life and Activity: New Challenges for Human Factors/Ergonomics. Symposium "Beyond Time and Space" STO-MP-HFM-231. STO NATO, 2014, pp. 8-1...8-8.

17. Pinchuk O. P. (2015), Historical and analytical review of social networking technologies and prospects of their use in training // Informacijni tekhnologhiji i zasoby navchannja [Information Technologies and Learning Tools], vol. 4, \# 48, pp. 14-34, available at: http://journal.iitta.gov.ua.

18. Litvinova S. G. Cloud-oriented design for learning environment of secondary schools. Foreign experience [Elektronnyj resurs] / S.Gh. Lytvynova // Informacijni tekhnologhiji i zasoby navchannja: elektronne naukove fakhove vydannja - 2014. - \#3 (41). - S. 10-27 - Rezhym dostupu: http://journal.iitta.gov.ua/index.php/itlt/article/view/1052/810\#.U7LD9ZR_toE.

Матеріал надійшов до редакиії 06.10.2016 p

\section{ІНДИВІДУАЛЬНІ МОЖЛИВОСТІ ТА НАВЧАННЯ ВПРОДОВЖ ЖИТТЯ}

\section{Буров Олександр Юрійович}

доктор технічних наук, провідний науковий співробітник відділу технологій відкритого навчального середовища

Інститут інформаційних технологій і засобів навчання НАПН України, м. Київ, Україна ayb@iitlt.gov.ua

Анотація. У статті описуються нові й виникаючі технології в сфері освіти та умовах навчання, а також методи, які повинні задовольняти особистості протягом усього життя, починаючи зі шкільного віку до виходу на пенсію, на основі психофізіогічної моделі формування когнітивних здібностей. Вона охоплює такі теми, як: оцінка здібностей й індивідуальних схильностей людини (враховуючи вікові особливості школярів, молоді та дорослих), індивідуальну траєкторію навчання, адаптивні стратегії та проектування навчання, рекомендації з розробки навчальних програм, щоденну підтримку для навчання 
людини, оцінку навчального середовища та продуктивності людини, рекомендації щодо професійної перепідготовки та/або подальшого кар'єри). Конкретна мета полягає в тому, щоб сприяти ширшому розумінню перспектив i підводних каменів цих технологій $\mathrm{i}$ середовища діяльності (навчання/викладання) в умовах глобальної освіти/розвитку, звертаючи особливу увагу на людину як суб'єкта в соціо-технічній системі та на співпрацю люди і техніки, дидактичні та організаційні підсистеми, а також на виникаючи проблеми кібер-безпеки.

Ключові слова: здібності людини; розвиток; навчальне середовище; психофізіологічна модель; безпека.

\title{
ИНДИВИДУАЛЬНЫЕ ВОЗМОЖНОСТИ И ОБУЧЕНИЕ В ТЕЧЕНИЕ ЖИЗНИ
}

\section{Буров Александр Юрьевич}

доктор технических наук, ведущий научный сотрудник отдела технологий открытой обучающей среды Институт информационных технологий и средств обучения НАПН Украины, г. Киев, Украина ayb@iitlt.gov.ua

\begin{abstract}
Аннотация. В статье описываются новые и возникающие технологии в сфере образования и условиях обучения, а также методы, которые должны удовлетворять личности на протяжении всей жизни, начиная со школьного возраста и до выхода на пенсию, на основе психофизиогичной модели формирования когнитивных способностей. Она охватывает такие темы, как: оценка способностей и индивидуальных склонностей человека (учитывая возрастные особенности школьников, молодежи и взрослых), индивидуальную траекторию обучения, адаптивные стратегии и проектирования обучения, рекомендации по разработке учебных программ, ежедневную поддержку для обучения человека, оценку учебной среды и производительности человека, рекомендации по профессиональной переподготовке и/или дальнейшей карьеры). Конкретная цель состоит в том, чтобы способствовать более широкому пониманию перспектив и подводных камней этих технологий и среды деятельности (обучение/преподавания) в условиях глобального образования/развития, обращая особое внимание на человека как субъекта в социо-технической системе и на сотрудничество человека и техники, дидактические и организационные подсистемы, а также на возникающие проблемы кибер-безопасности.
\end{abstract}

Ключевые слова: способности человека; развитие; учебная среда; психофизиологическая модель; безопасность.

Conflict of interest. The author has declared no conflict of interest.

\section{$(\mathrm{Cc})$ BY-NC-SA}

This work is licensed under Creative Commons Attribution-NonCommercial-ShareAlike 4.0 International License. 